\title{
More Than
}

\author{
Richard Bradley
}

'Entanglement' is not a new concept, but it has gained a wider currency since the publication of Ian Hodder's book in 20I 2. Because Hodder writes so clearly it is easy to engage with his ideas, whether or not one agrees with them. The subtitle of his study refers to 'The relationships between humans and things'. Christina Fredengren's keynote takes the subject further and considers sacrificial deposits containing the remains of people and animals. That is why her keynote is called 'Beyond entanglement'. She also considers an ethical dimension by considering 'power relations and practices of care' (Fredengren 2021:I3). How were the sacrificial victims selected? She considers 'what is tended to and what is excluded from benevolence and care' (Fredengren 2021:17). These are important issues.

Her argument is detailed and complex but, unfortunately, it is less lucid than Hodder's. The text sinks under the weight of specialised terms, some of them invented quite recently - agentiality, emotiality, and killability are simply examples. Most are taken from other authors, but that does not justify the obscurity. At times they congeal in a solid mass which is difficult for the reader to penetrate. Thus there are: 'material-semiotic-ethical entanglements' (Fredengren 2021:I7); 'ways of understanding workings or worldings of the world' (Fredengren 2021:19-20); and even 'the situated bodily agentiality of more-than-human-hybrid bodies' (Fredengren 202I:26). The 'language-tool' more-than-human is employed no fewer than sixteen times in a comparatively short article. I make this point because it took four readings before I felt comfortable that I understood Fredengren's argument. Since her main concern is with ethics, it will be a pity if her paper is incomprehensible to a wider audience.

Department of Archaeology, University of Reading

r.j.bradley@reading.ac.uk 
The fog bank of abstraction eventually gives way to an illuminating discussion of issues which could have been considered in more detail.

The first is her concern with ethics. She is right to recognise that certain beings - humans, animals, and possibly hybrid creatures - were poorly treated before they met their deaths. She identifies palaeopathological evidence for their condition when they died. They had received little care and some may have been considered 'less-then-human'. On the other hand, other victims were obviously well nourished and they do not fit the argument. Nor do those with physical anomalies (Sitch 20I9). What made it acceptable or possible to kill people? It is surprising that Fredengren makes no mention of the ancient writers who addressed this issue (Grane 2003), however difficult their texts are to interpret. Nor does she address the treatment of defeated war bands described in early sources and graphically illustrated by the human remains from Alken Enge (Løvschal et al. eds 2019). Written accounts say that such victims were sacrificed together with their animals and other possessions. It is obvious that they received exceptional treatment, but it is not clear whether she sees a lesson for archaeologists who work on this material. Certain living beings were excluded from 'benevolence and care' (Fredengren 2021:I7) in the past, but does she imply that modern researchers lack empathy in studying their remains? It would not apply to Melanie Giles's excellent account of bog bodies (Giles 2020).

A second point is equally important. While both people and animals could be killed, Fredengren is most concerned with hybrids. She offers a series of useful examples drawn from ethnography, folklore and ancient art, but her account is too short and she might have said more about beliefs in bodily transformation. This is unfortunate as some of the most compelling evidence comes from Northern Europe where it has been recognised for many years. It is not clear why hybrids made especially suitable victims, nor is their significance really documented by field archaeology. It is not enough to say that the remains of people and animals were deposited in the same contexts. What is the evidence that their identities merged? Were particular species of animals favoured? The remains of horses and/or dogs were particularly important at sites extending from La Tène to Skedemosse - were they selected because they had been closely associated with people in life? Perhaps the problem is most severe when their remains are found in water, for there can be taphonomic problems. There are dryland finds which ought to have been considered on equal terms. Among them are deposits in storage pits in which the bones of people and animals were combined to form composite skeletons. There are examples of this practice in Iron Age Britain (Hill 1995). Fredengren's example from Kvarntorp adds weight to her theoretical argument. She makes good use of this information but does 
not go into enough detail, although she cites other publications in which she has covered the ground in more depth.

Her discussion raises another issue concerning the role of composite creatures. As she says, much of the evidence for their significance comes from portable objects. They include swords with anthropomorphic decoration (Pearce 2013). Why are they excluded from this study, and why is nothing said about figurines or idols, like those found at Oberdorla where human and animal bones were associated with wooden 'altars' (BehmBlanke 2003)? Literary sources show that certain artefacts had histories and personal names - in that sense they were considered as animate. Living matter could be sacrificed, but if specialised objects shared the same attributes, the interpretation could extend to deposits of metalwork which could be destroyed, sometimes just as violently. The idea is worth considering since certain bogs and lakes are associated with a wide range of different deposits. They might contain human and animal bones during one phase and groups of fine objects in another. A good example is Vimose in Demark where twelve phases of activity have been recognised, four of them associated with deposits of living matter, and eight with groups of weapons (Pauli Jensen 2009). There were similar sequences at Skedemosse in Sweden (Monikander 20I0) and Llyn Cerrig Bach in Wales (McDonald 2007). Some deposits contained the remains of living creatures but very few artefacts. Elsewhere the emphasis was reversed (Bradley 20I7:58-79). Fredengren's category of the 'killable' may be too narrow.

Then there is a more general problem, for some of the empirical evidence on which she does draw has been well studied for many years and its distinctive characteristics were recognised some time ago. Her nonarchaeological sources are generally more recent. It is as if they have been assembled to add weight to ideas and approaches that had already developed in a less rigorous intellectual framework. This raises a wider problem, for contemporary archaeologists are constantly seeking alliances with other disciplines. In the past they drew on them for ideas and inspiration. Now it seems as if scholars who have already managed to deal with their material effectively are suffering from an inferiority complex in comparison with more profound thinkers and are turning to them for reassurance and legitimation. Fredengren's keynote is not the only paper in which an established body of knowledge merely adds credibility to theories in other, unrelated disciplines. The language changes as it passes through a filter of abstraction, but it is hard to see what this forced marriage has achieved.

In the end Fredengren's paper focuses so insistently on the 'more-thanhuman' that the phrase itself becomes a kind of motto running through the text. For a British reader the term has a curious connotation, as 'More Than' is the name of a successful insurance firm. It echoes Fredengren's 
discussion in another way because part of the company's business is to insure the lives of animals as well as those of humans. But that is the only connection. Its advertising slogan may be annoying, but it is adroitly aimed at its intended audience and is easy to understand. Need the writings of archaeologists - however elevated their themes - descend into a more-thanhuman obscurity?

\section{References}

Behm-Blanke, G. 2003. Heiligtümer der Germanen und ibre Vorgängern in Thüringen: Die Kultstätte Oberdorla. Stuttgart: Theiss.

Bradley, R. 2017. A Geography of Offerings: Deposits of Valuables in the Landscapes of Ancient Europe. Oxford: Oxbow.

Fredengren, C. 2021. Beyond Entanglement. Current Swedish Archaeology. Vol. 29 pp. II-33.

Giles, M. 2020. Bog Bodies: Face to Face with the Past. Manchester: Manchester University Press.

Grane, T. 2003. Roman Sources for the Geography and Ethnography of Germania. In: Jørgensen, J., Storgaard, B. \& Gebauer Thomsen, L. (eds), The Spoils of Victory: The North in the Shadow of the Roman Empire, pp. I28-I 45. Copenhagen: National Museum.

Hill, J.D. 1995. Ritual and Rubbish in the Iron Age of Wessex. Oxford: British Archaeological Reports.

Hodder, I. 20I2. Entangled: An Archaeology of the Relationships between Humans and Things. Oxford: Wiley-Blackwell.

Løvschal, M., Iversen, R. \& Holst, M.K. (eds). 2019. De draebte krigere i Alken Enge. Aarhus: Aarhus Universitetsforlag.

McDonald, P. 2007. Llyn Cerrig Bach: A Study of the Copper-alloy Artefacts from the Insular La Tène Assemblage. Cardiff: University of Wales Press.

Monikander, A. 20Iо. Våld och vatten: Våtmarkskult vid Skedemosse under järnåldern. Stockholm Studies in Archaeology 52. Stockholm: Stockholm university.

Pauli Jensen, X. 2009. From Fertility Sacrifices to Weapon Sacrifices: The Case of the South Scandinavian Bog Finds. In: Von Freeden, U., Friesinge, H. \& Warmers, E. (eds), Glaube, Kult und Herrenschaft, pp. 53-64. Bonn: Habelt.

Pearce, M. 2013. The Spirit of the Sword and Spear. Cambridge Archaeological Journal. Vol. 23 pp. 55-67.

Sitch, B. 2019. Bog Bodies and Sacrificial Theory. Journal of Wetland Archaeology. Vol. I9(I-2) pp. I54-I7I. 